\title{
CONSUMER BANKRUPTCY ABUSE
}

\author{
RAYMOND T. NIMMER*
}

\section{INTRODUCTION}

The relationship between federal bankruptcy and consumer credit is controversial and unsettled, owing to a clash of diametric views as to when individuals should be allowed to avoid obligations to pay their debts. The result is a complex, compromissary structure of uncertain content and variable application, one aspect of which-a general concept of "bankruptcy abuse"-relates to bankruptcy planning and the selection among bankruptcy options by individual debtors. Although the rules that govern such abuse should reflect coherent policy judgments, often they do not because connections among the various underlying substantive issues are unrecognized or ignored.

Consumer bankruptcy law relating to the discharge of debts is similar to contract doctrines of impossibility, cure, and insecurity, each of which expressly defines legally acceptable options that permit less than complete contract performance under specified circumstances. So, too, in bankruptcy, incomplete performance-the nonpayment of debt-may be legally sanctioned, absent a finding that the process has been abused. Abuse may be found in the debtor's motivations for filing, in the manner in which he has dealt with his creditors and assets prior to filing, or in a demonstrated lack of need for bankruptcy relief.

\section{II}

\section{Defining the Dispute}

The interface of bankruptcy law with nonbankruptcy law and practicel is marked with conflict, and resolution of that conflict requires a measure of perhaps uneasy accommodation on one side or both. ${ }^{2}$ For example, the

\footnotetext{
Copyright $\odot 1987$ by Law and Contemporary Problems

* Law Foundation Professor of Law, University of Houston Law Center; Counsel, Sheinfeld, Maley and Kay, Houston, Texas.

1. See Nimmer, Executory Contracts in Bankruptcy: Protecting the Fundamental Terms of the Bargain, $\mathbf{5 4}$ U. Colo. L. Rev. 507 (1983); Eisenberg, Bankruptcy Law in Perspective, 28 UCLA L. Rev. 953 (1981); Jackson \& Kronman, Secured Financing and Priorities Among Creditors, 88 YALE L.J. 1143 (1979); Jackson \& Kronman, Voidable Preferences and Protection of the Expectation Interest, 60 MinN. L. REv. 971 (1976); Countryman, The Use of State Law in Bankruptcy Cases, 47 N.Y.U. L. REv. 407, 631 (1972); Shimm, The Impact of State Law on Bankruptcy, 1971 DUKE L.J. 879.

2. For example, federal bankruptcy law induced major revisions of state exemption rules. In 1978, federal exemptions were adopted and made available in bankruptcy as an alternative to state law exemptions. II U.S.C. $\$ 522$ (1982). The Bankruptcy Code, however, provided that a state could expressly elect to exclude these federal, alternative exemptions from use by its citizens. Id.
} 
bankruptcy notion that under at least some circumstances a debtor should be relieved of his obligation to pay his debts collides with the more general expectation that he will pay them. ${ }^{3}$ The tensions created by efforts to reconcile these antithetical propositions in the consumer credit context are reflected in the definition of consumer bankruptcy abuse.

Most consumer bankruptcies are initiated by the debtor, who has chosen this course from among several available options, including voluntary repayment, refinancing, absconding, and ignoring creditor pressure. His choice may have been rational, planned, and fully informed, or it may have been emotional, unstudied, and uneconomic. Historically, however, this unilateral decision by the debtor has been permitted to define the role of bankruptcy in the consumer credit context, and standards of abuse have performed only a limited monitoring function in narrowly circumscribed kinds of cases.

This "natural state" definition of the role of consumer bankruptcy has been accepted for many years. Indeed, prior to 1984, most reforms in the area were directed at expanding the debtor's protection against oppressive debt-collection practices and increasing his retained property potential rather than at constraining his choice of an insolvency remedy. After passage of the Bankruptcy Code in 1978, however, the dramatic increase in the rate of individual bankruptcy filings was widely ascribed, at least in part, to its overly attractive debtor benefits. This perception animated many of the consumer bankruptcy reforms introduced into the Code by the 1984 amendments. ${ }^{4}$

$\S 522$ (b)(1). As a result, a substantial majority of all states were moved to reexamine and modernize their exemption laws, and many simultaneously "opted out" of the federal alternative exemptions. 1 W. Norton, Bankruptcy Law AND Practice $\$ \S 26.06-26.10$ (1986). Although in many cases these state exemptions differ markedly from the federal exemptions, they do at least reflect a contemporary reconsideration of the underlying policy issues. See generally Woodward, Exemptions, Opting Out, and Bankruptcy Reform, 43 Oнiо ST. L.J. 335 (1982).

Federal bankruptcy rules paralleled and, in fact, led nonbankruptcy developments regarding the "blanket" security interest involving consumer goods. A blanket security interest in consumer goods encompasses all of the debtor's property even though the loan that it secures did not finance the purchase of the covered items. To the extent that the interest extends to household goods, it is reasonable to believe that it has been designed merely to establish undue leverage over the consumer without any intent by the creditor to foreclose in the event of default. Initially, in the 1960's, the Uniform Commercial Code established limits on the ability of a creditor to encumber after-acquired consumer property. U.C.C. \$ 9-204(2) (1977). Subsequently, in 1978, the consumer debtor was empowered to avoid such security interests in bankruptcy to the extent that they impaired his exemptions. 11 U.S.C. $\$ 522(f)(1982)$. This protection was then expanded in 1985 by a Federal Trade Commission Rule which provided that a blanket security interest created by a consumer credit agreement constitutes an unfair practice. See 16 C.F.R. $\$ 444.2(a)(4)$ (1986).

In contrast, the Bankruptcy Code incorporates provisions that separate a creditor's right to a deficiency claim from the leverage based on his claim to collateral. 11 U.S.C. $\$ \$ 506,722$ (1982); but FTC proposals that would have reduced the creditor's right to pursue a deficiency outside of bankruptcy were not adopted. See 16 C.F.R. $\$ 444$ (1986).

3. Compare Goetz \& Scott, Enforcing Promises: An Examination of the Basis of Contract, 89 YALE L.J. 1261 (1980), with Schwartz, The Case for Specific Performance, 89 YaLE L.J. 271 (1979), and Kronman, Specific Performance, 45 U. ChI. L. Rev. 351 (1978).

4. See Vukowich, Reforming the Bankruptcy Reform Act of 1978: An Alternative Approach, 71 GEo. L.J. $1129,1129-31$ (1983). 
These reforms sought to reduce incentives for inappropriate bankruptcy filings and to discourage otherwise objectionable behavior by individual debtors. The difficulty has been, however, not only that we know little about how or why such a debtor makes his decision concerning bankruptcy, but also that we do not even necessarily agree as to what his decision in any particular case should be. This confusion is reflected in the law's current attempts to both encourage and deter voluntary use of bankruptcy by consumer debtorsa classic illustration of policy compromise without reconciliation. Furthermore, a lingering suspicion exists that neither desired effect routinely filters through to actual decisions by actual individual debtors facing what they define as a "need" for bankruptcy.

The law of consumer bankruptcy abuse thus operates in a doubly-blind situation. First, hunches are substituted for data on the nonperformance of consumer credit contracts. In place of data, slogans document abuse. Doctrinaire assumption is injected in place of understanding. One common assumption, echoing economics theory, is that consumers who are under debt pressure and who lack legal advice nevertheless rely upon an informed, rationally measured balancing of costs and benefits when deciding whether to perform under their credit contracts. This view contradicts both normal experience and the assumptions on which most consumer credit regulation is based. But alternative models that have been propounded are even less clear and provide even less explicit guidance as to the mechanics of consumer behavior. ${ }^{5}$

There is, moreover, only minimal agreement about what consumer debtor behavior is abusive. This becomes clear both in considering the relationship between a debtor's income and the propriety of his discharge in bankruptcy and in determining the extent to which debtors legitimately can plan to optimize bankruptcy effects. ${ }^{6}$ Consensus on policy is confined to the periphery. Abjectly poor, harassed debtors forced into poverty by uncontrolled circumstances clearly should qualify for bankruptcy relief. Persons with high incomes and few debts who deliberately transfer and hide assets to maximize the property they retain should not qualify for such relief. Between these extremes, however, there are sharp unresolved disagreements as to when consumer bankruptcy should be sanctioned.

Bankruptcy doctrine does not generally address these anomalies, but rather relies on the decisions of individual debtors to define the role of bankruptcy in their own particular cases. Abuse law, however, represents the

5. See LoPucki, A General Theory of the Dynamics of the State Remedies/Bankruptcy System, 1982 WIS. L. REv. 311; Leff, Injury, Ignorance and Spite-The Dynamics of Coercive Collection, 80 YALE L.J. 1 (1970). See also Shuchman, Profit on Default: An Archival Study of Repossession and Resale, 22 Stan. L. Rev. 20 (1969); Note, Business as Usual: An Empinical Study of Automobile Deficiency Judgment Suits in the District of Columbia, 3 ConN. L. Rev. 511 (1971). For a brief discussion of secured lender leverage efforts, see 1 P. Coogan, W. Hogan \& D. Vagts, Secured Transactions Under The Uniform Commercial Code $\$ 1.04(3)(1986)$.

6. See Vukowich, supra note 4, at 1130-31; Warren, Reducing Bankruptcy Protection for Consumers: $A$ Response, 72 Geo. L.J. 1393 (1984); Vukowich, A Reply to Professor Warren, 72 Geo. L.J. 1359, 1364-65 (1984). 
exception: It is defined by standards couched in terms of excess and of broad norms of fair dealing that focus on income-shifting, transfer of assets, and fraudulent prepetition conduct.

\section{III}

\section{Section 707(B): Abuse of Chapter 7 Relief}

Only one section of the Bankruptcy Code expressly refers to "abuse" by an individual debtor. Notwithstanding a presumption in favor of the relief requested by the debtor, section 707 (b) provides that the court may dismiss a chapter 7 liquidation case if granting the debtor a discharge would be a "substantial abuse of the provisions" of that chapter. ${ }^{7}$ Exercise of this judicial power is limited to cases involving individuals whose debts are primarily consumer debts. ${ }^{8}$

Section 707(b) thus introduces judicial authority to review the propriety of a chapter 7 proceeding and imposes direct restraints on the debtor's ability to obtain bankruptcy relief. Section 707 (b) provides that dismissal must be on the court's own motion, thus recognizing a public interest in preventing bankruptcy abuse and authorizing an independent judicial monitoring function not limited to the court's traditional role of responding to motions and complaints.

The statute, however, supplies no substantial guidance to a court seeking to determine if a bankruptcy filing impermissibly deviates from acceptable social policy standards. Because the court is not acting on a motion by a party in interest, dismissal must be based not on proven or provable harm to a particular creditor, but rather on actions or circumstances that bear more broadly on the role of bankruptcy in the consumer credit context.

The lack of articulated standards and the unique, self-actuating method of raising the issue of dismissal sanctioned by section $707(\mathrm{~b})$ creates a serious policy risk. Because the role of bankruptcy in this context has largely been defined by ad hoc, personal decisions of individual debtors and because these decisions will likely be restrained by similarly ad hoc and personal decisions of bankruptcy court judges, both sets of decisions may be based on no more than subjective prudential notions concerning the relationship between bankruptcy discharge and the moral obligation to pay debts. The existence of this risk counsels against aggressive, pro-active judicial monitoring and in favor of judicial circumspection in acting under section 707(b). In general, then, as discussed below, dismissal of a consumer bankruptcy petition should be restricted to cases involving either (1) an existing statutory basis on which discharge of all debts could have been denied if a creditor had raised the issue; or (2) a provable ability to pay substantially all debts out of the debtor's current income if there were no liquidation.

7. 11 U.S.C. $\S 707$ (b) (Supp. III 1985).

8. Id. 


\section{A. Abuse and Public Interest}

Although a chapter 7 proceeding ordinarily discharges all debts, section 727 lists several events that will support the denial of the discharge of any claims. ${ }^{9}$ These objections to discharge focus on actions by a debtor that adversely affect all creditors or the integrity of the bankruptcy process, and they must be expressly raised by a party in interest. Because in many consumer cases the likely economic return supplies inadequate incentive for creditors to involve themselves or even participate in the proceedings, section 727 objections are seldom filed. Nevertheless, the factual bases on which a discharge could have been denied under section 727 are probably cognizable as "substantial abuse" under section 707(b).

Thus, it should be a bankruptcy abuse for a debtor to obtain a discharge if a valid objection could have been-but was not-raised by a creditor. The section 727 objections properly lie if the debtor has made fraudulent conveyances before filing, failed to account for lost assets, or failed to comply with important obligations imposed upon him in chapter 7 . These acts not only prejudice creditors, but also compromise the integrity of the bankruptcy itself. Creditor inaction does not suspend the public interest in denying a discharge to the debtor in such cases.

In contrast, "substantial abuse" should not incorporate the provisions of section 523, which excepts from discharge particular debts owing to their distinctive character or the manner in which they were incurred. Some of these exceptions relate to acts to defraud particular creditors or to the fact that the debt was incurred through willful and malicious injury of another. ${ }^{10}$ Section 523 also excepts such debts as taxes and support and alimony claims. Only the interest of the individual creditor involved is at stake under section 523, and it is properly incumbent on him to protect his own interest. Where, of course, a general pattern of fraudulently incurred debts emerges shortly before bankruptcy, the situation may be different. Absent such a pattern, however, section 523 reflects a policy of protecting only the affected individual creditor, and courts should not read this policy into section 707 (b) to deny a debtor a discharge of all of his debts.

Section 707(b) also provides the court with a method to monitor a debtor's good faith efforts to comply with reporting and other obligations imposed on a debtor in bankruptcy. The result of such monitoring was illustrated in In re Bryant, ${ }^{11}$ where the court, emphasizing the equitable nature of bankruptcy relief, dismissed a chapter 7 petition under section 707 (b). It rested its finding of substantial abuse on two factors. First, there were indications that the debtor could pay as much as two-thirds of his existing debts from income if he adjusted an extravagant lifestyle that, in light of his assets, the court regarded as inconsistent with a need for bankruptcy relief. And second, the

9. 11 U.S.C. $\$ 727$ (1982). See 1 W. NorTon, supra note 2, at $\S \S 27.14-27.25$.

10. 11 U.S.C. $\S 523$ (1982 \& Supp. III 1985).

11. 47 Bankr. 21 (Bankr. W.D.N.C. 1984). 
court observed that the debtor had not complied with reporting obligations, but rather had concealed debts and assets while inflating expense estimates:

[T]he Court finds on the part of the Debtor an utter disregard of his duties under the ... Code to truthfully list all of his obligations, his monthly expenses, and to disclose his general financial postion to the Court ... . Such selective disclosures and recollections act as a fraud upon the Court .... As such the Court will not tolerate them while at the same time shielding the Debtor from those whom he rightfully owes. ${ }^{12}$

\section{B. Abuse and Ability to Pay}

Section 707(b) permits the court to consider whether the debtor's income establishes a need for bankruptcy relief. It is an abuse to file under chapter 7 if current and foreseeable future income as measured against reasonable expenses is substantially sufficient to pay existing debts. This standard, which is central to section $707(\mathrm{~b})$, stems from legislative proposals that would have required that the debtor pay all "affordable" debt from his income. Although these proposals were rejected, section 707 (b), along with a new requirement that the debtor file a statement of earnings and current expenses, ${ }^{13}$ provides for a more limited review of the relationship between the debtor's income and his debts that is designed to prevent his discharge in liquidation in the face of high disposable income.

The original proposals that evolved into section 707(b) contemplated quite dramatic changes in the role of chapter 7 in the consumer credit context. A credit industry proposal would have limited consumer bankruptcy to income-based proceedings if the debtor could pay a "reasonable portion of his debts out of anticipated future income" that was "not needed ... for the support of himself and his dependents." 14 An alternative, supported by an American Bar Association committee, would have given creditors a right to request judicial review of the debtor's income and payment capability and would have empowered the court to dismiss the petition if the debtor was capable of paying a reasonable amount of his debt. ${ }^{15}$ The ABA Committee proposed that chapter 7 relief not be "something which should be available for the asking ... [but rather that it be] a form of equitable relief which should be justified by the exigencies of the consumer's financial condition." 16 But section 707(b) inverts the presumption and softens the standard: Chapter 7 relief is available unless a court denies access based on available income for the payment of debts.

These restrictive proposals were based on a belief that consumer use of bankruptcy was becoming uncontrolled. The underlying policy judgment was that bankruptcy liquidation is appropriate only in cases where there is a

12. Id. at 25 .

13. 11 U.S.C. $\$ 521$ (Supp. III 1985).

14. Proposed Bankruptcy Improvements Act of 1981, S. 2000, 97th Cong., 1st Sess., 127 Cong. REC. 32,195 (1981).

15. Report and Recommendations: Consumer Bankruptcy Subcommittee of the Committee on Consumer Financial Services of the American Bar Association, 2 N. ILL. L. REv. 239, 259-61 (1982).

16. Id. at 259. 
general inability to pay debts. The underlying assumption was that the debtor's decision should be based solely on whether he could pay his debts, with bankruptcy serving as a back-up, secondary option to be invoked only when the debtor's financial predicament would be otherwise unmanageable.

The policy issue thus related to the reasons for and timing of the debtor's decision to file bankruptcy rather than pay his debts. Leaving this decision to unfettered consumer choice effectively created a "natural state" definition of the role of bankruptcy that equated practice with acceptable policy. A "natural state" policy assumes that social, economic, and interpersonal influences adequately shape consumer decisions to conform to a desired model that in most cases limits bankruptcy to persons in serious economic distress. But the credit industry argued, based on the large increase in bankruptcy filings, that legal and environmental changes had altered the "natural state" model. Among these allegedly influential changes were more liberal discharge benefits, increased property protections, and shifting social perceptions that reduced the stigma of a bankruptcy filing. In short, these changes created a sense that the overall benefits under the system were now too favorable to the debtor. Industry representatives alleged that as a result, liquidation too often became a primary option, selected readily by the debtor without sufficient effort having been made to pay. ${ }^{17}$ This conclusion was based on assumptions about the behavior of consumer debtors for which the only supporting empirical data were supplied by a questionable study of bankrupt debtors. ${ }^{18}$

Most of us would agree that bankruptcy discharge is neither necessary nor especially desirable for debtors who are able to pay and are under no great countervailing pressure. This general agreement, however, masks significant disputes that surround what constitutes ability to pay, how it should be measured, what burdens a debtor should be required to accept, and whether statutory standards to regulate access to liquidation and discharge are justified by prevailing levels of abuse. ${ }^{19}$ The credit industry proposed that liquidation should be available only in the worst cases of financial distress and defined "worst case" as an inability to pay even a reasonable portion of existing debts from income. Liquidation discharge under this formulation would be reserved for cases of virtually total income failure and would be calibrated to a defined inability to pay determined by a court rather than by the debtor.

Traditionally, in a liquidation case, the debtor's income potential has been ignored, and a creditor's right to payment has been measured in terms of the debtor's current assets. The credit industry's proposals, however, looked to the debtor's income as the crucial determinant of both his right to file and his

17. See Vukowich, supra note 4 .

18. See 1 Credit Research Center, Krannert Graduate School of Management, Purdue University, Consumer Bankruptcy Study ii (1982) (research commissioned by credit industry). See also Warren, supra note 6 , at $1338-39$ (criticizing study commissioned by credit industry).

19. See Warren, supra note 6, at 1338-39; Vukowich, supra note 6, at 1962-63. 
creditors' right to payment. One supporter suggested: “Repayment plans that draw upon future earnings more accurately reffect a debtor's ability to pay than do liquidation plans. We live to a great extent in a cash flow world."20 From this perspective, then, a chapter 7 filing should be based on income failure alone; a liquidation filing on any other basis would constitute an abuse if the debtor's future income could, nonetheless, provide substantial recovery for his creditors.

The income model reflects the view that creditors should have access to the debtor's future income and that liquidation bankruptcy unfairly deprives them of access to this resource. In a liquidation proceeding, a creditor's recovery is converted from an expectancy of payment out of the debtor's income to payment from his fixed, existing assets. If future income is an asset or valuable expectancy, liquidation shields this asset from creditor claims and converts it fully to the debtor's personal use. Fulfillment of the expectancy of payment, however, requires voluntary action by the debtor, while the proposed bankruptcy model would compel payments in return for discharge.

Some shifting of income assets away from creditors in a liquidation is justified on policy grounds, and this is anticipated in a liquidation system even under the rejected credit industry proposals. Future income supports the fresh economic start for the debtor. Consequently, if the income is marginal, equitable considerations and economic reality justify denying creditors access to it and reserving it instead to the debtor. Indeed, the bankruptcy goal of facilitating a fresh state for the debtor ordinarily incorporates at least some flexibility in income control.

Some debtors, however, have high disposable income but few tangible, nonexempt assets. A liquidation discharge absolves such debtors of liability to creditors who may have received little or no payment but leaves these debtors with substantial future income to which their creditors will be denied access. This sequence of effects forms the primary model underlying the drive for reform. How often such high-income filings occur is not known. Under a "natural state" model, however, bankruptcy law historically has permitted high-income liquidation, the debtor being restrained only by social considerations and his judgment about whether the benefits justify relinquishing his current assets and damaging his credit standing.

Outside of bankruptcy, the relationship between income and debt collection involves voluntary payments, most often animated by a moral obligation to pay. Because voluntary payments are common, decisions to extend credit are frequently based not on the debtor's assets, but rather on his projected income. A bankruptcy liquidation sharply changes the focus to tangible, current assets. "The rights of unsecured creditors, who may lend at least in part on an expected flow basis, and the debtor, who borrows on the

20. See Eisenberg, supra note 1, at 980. 
same basis, suddenly are determined solely by the value placed on the debtor's nonexempt assets on the date of bankruptcy."21

Voluntary payment, however, does not completely define a system of legally protected creditor reliance on the debtor's income. The judicial collection system emphasizes levy and execution against nonexempt assets. And wage garnishment is controversial and restricted by law, ${ }^{22}$ ordinarily available-even where it is sanctioned-only if the creditor first has exhausted his remedies against the debtor's other assets. Moreover, as illustrated by recent FTC rules limiting contract wage assignments, the national pattern is moving away from coercive access to wages for debt collection. ${ }^{23}$ The debtor's income is not the primary element in the legal collection system, and it should not be the primary element in the bankruptcy discharge system.

The fact that mandatory income proposals were rejected in drafting the Bankruptcy Code bears on the proper interpretation of "substantial abuse" in section 707(b). Congress did not confine bankruptcy liquidations to cases in which the debtor was unable to pay from income. Instead, the new law deviates only slightly from a "natural state" model, with primary discretion concerning the initiation of proceedings remaining in the debtor. Judicial restraints affect only cases of substantial abuse.

Such abuse may occur when there is a shifting of income that is patently not required by the debtor's reasonable financial needs. The Code adopts a discretionary review standard to curtail cases of egregious abuse without converting consumer bankruptcy entirely into a wage-based remedy. This solution limits dismissals to cases in which the debtor has the demonstrable ability to pay substantially all of his debts within a reasonable time. Tests satisfiable by a lesser ability to pay would reinstate the rejected mandatory income proposals.

A standard of substantiality must consider not only the debtor's income, but also the liabilities and ordinary expenses that must be offset against that income. Section 707(b) poses an equity test in which motivations are important. Accordingly, a bankrupt debtor may reasonably be required to demonstrate some sacrifice or a genuine effort to deal fairly with his creditors as a precondition to obtaining a discharge. It is not appropriate, however, for a court to hold the debtor to its own assessment of the minimum support needs for him and his dependents and to calibrate this imposed level to bare subsistence-although this control on the court does not suggest that a court must uncritically accept the debtor's projections as the sole determinant of what funds are left to pay his creditors.

21. Id. at 981 .

22. See Consumer Credit Protection Act, 15 U.S.C. $\S 1671-77$ (1982). See also Cal. Civ. Proc. Code $\$ 704.070$ (West Supp. 1986); N.Y. Civ. Prac. L. \& R. \$§ 5205(d), 5231 (McKinney 1978 \& Supp. 1986); Tex. Civ. Prac. \& Rem. Code $\$ 63.004$ (Vernon 1986).

23. See 16 C.F.R. \$ 444.2 (1986). 
The reported cases under section 707(b) reflect judicial efforts to effect a fair balance. For example, in In re Grant ${ }^{24}$ a debtor earning $\$ 65,000$ a year originally reported monthly expenses estimates for a family of four of $\$ 4,806$. These estimates were later reduced to $\$ 3,333$, but they were still described by the court as inflated and excessive since they included almost $\$ 900$ for two cars, $\$ 450$ for entertainment, and $\$ 550$ for clothes. The court dismissed the case because it found no sudden hardship causing financial distress, a lack of sincere effort by the debtor to tighten his financial belt, and an actual ability to pay over sixty percent of his unsecured debt over a five-year period. Failure of the debtor to propose a reasonable family budget was held to indicate bad faith.

In In re Mastroeni ${ }^{25}$ the debtor had an annual income of $\$ 73,000$ and unsecured debt of $\$ 110,000$, largely accumulated from failed speculative investments. His statement of expenses reported a monthly net income of $\$ 4,000$ and expenses of $\$ 3,980$, including almost $\$ 900$ for entertainment and recreation, coupled with $\$ 600$ for "supplies." The court noted that the debtor's monthly expenses were obviously inflated. Borrowing language from In re Bryant, the court noted that "even if these amounts are accurate, the Court has serious questions about their appropriateness" for a debtor in chapter 7. Bankruptcy liquidation is not designed "to allow the Debtor to lead the life of Riley while his creditors suffer . . ."26

Similarly, in In re Bryant ${ }^{27}$ the court's dismissal of a case under section 707(b) was bolstered by a finding that with a modicum of restraint, the debtor could have paid more than sixty-seven percent of his liabilities over three years from an annual income of in excess of $\$ 40,000$ for a family of four. The court questioned the accuracy of some elements of a monthly expenses estimate of $\$ 3,500$ that would have consumed the debtor's entire net income but went on to suggest that even if they were accurate, the submitted estimated expenses for two late model cars, cable television, and entertainment reflected a lifestyle inconsistent with the debtor's asserted need for chapter 7 relief.

The implicit financial model in cases such as Bryant posits relative frugality, if not abstinence, as a precondition to chapter 7 bankruptcy. This approach was amplified in In re Hudson, ${ }^{28}$ in which the court commented that chapter 7 provides "relief to a debtor when he finds himself in financial circumstances which threaten his immediate well-being." In Hudson relief was granted on the basis of a general standard that requires dismissal if the debtor has a capability to pay a "substantial portion" of his debts. Other courts refer to "meaningful" payment. But the label is immaterial. The core consideration

24. 51 Bankr. 385 (Bankr. N.D. Ohio 1985).

25. 56 Bankr. 456 (Bankr. S.D.N.Y. 1985).

26. Id. at 458 .

27. 47 Bankr. 21 (Bankr. W.D.N.C. 1984).

28. 56 Bankr. 415 (Bankr. N.D. Ohio 1985). 
involves the degree of self-denial sacrifice expected of a chapter 7 debtor who has an expectation of income.

The abuse issue arises only if the court decides to raise it, ${ }^{29}$ and opinions are reported only if the court decides to publish them. Although many such reported opinions construe section $707(\mathrm{~b})$ to require close scrutiny of the debtor's affairs and a consequent finding that he will otherwise suffer substantial financial hardship before he may qualify for bankruptcy relief, this view does not command universal judicial support. In In re Mastroeni, ${ }^{30}$ for example, while the court questioned the accuracy of the debtor's projected expenses, it held that a debtor has a right to bankruptcy relief and refused to dismiss the petition under section 707 (b) because the debtor was ineligible for either chapter 11 or chapter 13 relief. Other courts have rejected close review of the debtor's income and expense projections, reasoning that the "substantial abuse" test can appropriately be invoked to justify exclusion of only extreme cases. Thus, in In re Edwards ${ }^{31}$ the court, in forebearing to dismiss the debtor's petition under section 707(b), took the opportunity to comment that it would review few cases and would normally give deference to the debtor's reported expense estimates.

It may fairly be concluded that section 707(b) does not require extreme financial hardship as a precondition to a grant of bankruptcy relief under chapter 7. The substantial abuse standard requires no specific levels or degrees of hardship, but only requires genuine effort and fair dealing by the debtor. When bankruptcy can be related to identifiable and unexpected financial setbacks, a debtor seeking relief is guilty of no abuse. ${ }^{32}$ Such a debtor with an expectation of income qualifies for chapter 7 relief if he previously has made good faith efforts-whether or not successful-to pay and to protect his creditors' interests in receiving payment. Where, however, the debtor has acted otherwise, dismissal is appropriate. The debtor in Bryant misstated or concealed assets, and the debtor in Grant failed to propose a reasonable budget and piled up cash advances and consumer purchases in excess of his ability to pay. In both cases, the finding of abuse turned not only on a close assessment of the debtor's income potential, but also more broadly on the view that to obtain relief in bankruptcy, the debtor must deal honorably with his creditors.

29. See In re Christian, 51 Bankr. 118 (Bankr. D.N.J. 1985) (court cannot act on trustee or creditor suggestion). But see In re Hudson, 56 Bankr. 415 (Bankr. N.D. Ohio 1985) (court overlooks limited creditor involvement in raising the issue).

30. 56 Bankr. 456 (Bankr. S.D.N.Y. 1985).

31. 50 Bankr. 933 (Bankr. S.D.N.Y. 1985).

32. See In re White, 49 Bankr. 869 (Bankr. W.D.N.C. 1985) (petitioner subject to large tort judgment not guilty of abuse). 


\section{IV}

\section{Abuse and Prebankruptcy Planning}

Most consumer bankruptcies are initiated voluntarily by the debtor after his assessment of the relative pros and cons of available alternatives. Accordingly, some debtors will seek to structure their affairs to optimize the benefits of their choice. In most cases, the decision to file bankruptcy and the selection of a bankruptcy format (i.e., chapter 7 or chapter 13) is not directly constrained by law. Similarly, subject only to a lien created by contract or law, a debtor normally retains absolute control of his assets, enjoying the right to convey and use that property for his maximum personal benefit prior to his filing bankruptcy.

Some indirect constraints do, however, apply. These constraints entail balancing the need of the debtor for flexibility with the need of creditor interests for protection against excessive debtor manipulation. Thus, the individual debtor's use or acquisition of property is limited by standards defining fraud and misrepresentation. Further, the Bankruptcy Code limits some eve-of-bankruptcy transfers to particular creditors: In some instances, not only may the transfer be avoided, but the debtor may also be barred from discharge of any of his debts. ${ }^{33}$ In other instances, a particular debt may be excluded from discharge or the recovery of the transferred property may be permitted. ${ }^{34}$

In general, however, a debtor may arrange his assets and selectively pay creditors to his benefit. Such planning by lawyers to maximize a business client's gain is common, but such planning for consumers is less well accepted and has encountered some emotional objection. ${ }^{35}$ From one perspective, planning is seen as manipulation, altering the effects of the bankruptcy process in a manner that arguably constitutes abuse. This view assumes that all consumers should naively base their decisions on nonlegal factors. In practice, however, consumers do so only if they act without informed advice; soundly counseled, they adjust their behavior in response to known risks and anticipated contingencies. ${ }^{36}$ The proper policy question thus focuses on the type and degree of planning that is permissible.

Consumer debtor planning is neither more nor less acceptable and inevitable than business debtor planning. In consumer cases, however, consideration of what controls are appropriate requires not only a judgment about what planning is unobjectionable, but also a realistic view of how planning decisions are actually made. There is a temptation to assume that individuals are adequately informed and act rationally or have access to

33. 11 U.S.C. \$ 727 (1982 \& Supp. III 1985).

34. See 11 U.S.C. $\$ 547$ (1982 \& Supp. III 1985) (transfer avoidable if preferential and not exempted); 11 U.S.C. \$ 523(a)(2) (Supp. III 1985) (debt not discharged when incurred by fraud).

35. See Eisenberg, supra note 1, at 992-94.

36. See Nimmer, supra note 1; Nimmer, Secured Creditor and the Automatic Stay: Variable Bargain Models of Fairmess, 68 MinN. L. REv. 1 (1983); Jackson, Bankruptcy, Nonbankruptcy Entitlements, and the Creditors' Bargain, 91 YALE L.J. 857 (1982); Eisenberg, supra note 1, at 992. 
counsel to aid in assessing choices. In fact, however, although some consumer debtors may have foreknowledge of bankruptcy effects, in many cases they lack legal sophistication and act without the benefit of competent professional advice. A lawyer may be retained to prepare and file the bankruptcy petition, but he is often not involved until the last moment, after many important decisions may already have been made. Even then, the lawyer-client relationship is often so brief and of such limited scope as to rule out significant adjustment of the debtor's financial status prior to filing.

Several distinct patterns of planning occur in consumer bankruptcies. In one, the individual debtor, naive and uncounseled, makes no effort to adjust his economic condition in contemplation of bankruptcy. When a lawyer is contacted, he makes no suggestions about restructuring the debtor's assets. He may view consumer bankruptcy planning as ethically inappropriate; or such planning may be either impossible, owing to the debtor's indigency, or unnecessary, because the debtor will receive maximum discharge benefits and lose no assets without any further adjustment. Alternatively, the lawyer may lack the necessary knowledge or time to render such planning service. In any event, the debtor files in a truly "natural" condition. Significantly, the limited empirical evidence available suggests that this pattern is seen in most consumer bankruptcy cases. ${ }^{37}$

In a variant pattern, the lawyer who prepares the bankruptcy petition assumes a more active role and advises the debtor to optimize his position prior to filing. ${ }^{38}$ To this end, the debtor engages in last-minute transactions, converting assets from one form to another or making payments to retain relationships with particular creditors-for example, paying the utility company, paying the home mortgage.

In another variant, the debtor early recognizes the possibility of bankruptcy and begins accordingly to adjust in order to optimize his position. In some cases, these early adjustments are informed by expert advice, but more often the debtor shifts assets and grants preferences based on a colloquial or "intuitive" knowledge of the legal effect of such actions. ${ }^{39}$ When a lawyer is eventually involved in a case so structured for bankruptcy, many of the transactions are completed, and the only remaining issue is whether and how any harm to the debtor can be avoided by timing the filing.

37. See D. Stanley \& M. Girth, Bankruptcy: Problems, Process, Reform 47-49 (1971) (bankruptcy filing precipitated by collection efforts, often preceded by severe financial setback); Shuchman, The Average Bankrupt: A Description and Analysis of 753 Personal Bankruptcy Filings in Nine States, 88 CoM. L.J. 288 (1983); Woodward \& Woodward, Exemptions as an Incentive to Voluntary Bankruptcy: An Empirical Study, 88 Com. L.J. 309 (1983). See also I Credit Research Center, Krannert Graduate School of Management, Purdue University, Consumer Bankruptcy Study 35 (1982). This is not to suggest, however, that planning does not occur. See Resnick, Prudent Planning or Fraudulent Transfer? The Use of Nonexempt Assets to Purchase or Improve Exempt Property on the Eve of Bankruptcy, 31 RuTGERS L. REv. 615, 643-46 (1978).

38. See Resnick, supra note 37.

39. See, e.g., In re Reed, 700 F.2d 986 (5th Cir. 1983). 
As these patterns suggest, the fact that transactions occur shortly before bankruptcy does not, in itself, necessarily indicate fraud or illegality. ${ }^{40}$ Although legal doctrine affecting business cases may correctly assume the availability of long-term guidance and advance planning and may regard eveof-bankruptcy transactions with some suspicion, a similar assumption in consumer cases belies reality. The opportunity for counseled planning in these cases often does not arise until just before filing. Consumer debtor behavior shortly before bankruptcy should not be immune from scrutiny, but a doctrine categorically voiding eve-of-bankruptcy transactions would be overbroad and would substantially nullify the ability of such debtors to plan for bankruptcy.

Similarly, the fact that a debtor has acted after consulting counsel does not necessarily indicate fraudulent motivation. In business cases, it is acceptable for clients routinely to consult counsel prior to filing; and in consumer cases, analogous planning should not be characterized as illicit or unethical. Depending on what transactions are effected after the consultation, the debtor's conduct may, in fact, give meaningful expression to the ideal that individuals should be fully informed of their legal rights.

Prebankruptcy transactions often involve no express consideration of bankruptcy. Individual debtors generally perform only a relatively superficial analysis of the potential effect of their prebankruptcy transactions. The behavior of individuals under stress is often erratic and irrational, and this pattern must be considered in developing doctrines to define the range of acceptable prebankruptcy conduct by an individual debtor. Finely tuned, technical approaches are inappropriate. Concepts of deterrence cannot be based on detailed foreknowledge by the debtor of the consequences of his acts. Rather, doctrines applicable to consumer behavior should be flexible and intuitively obvious, permitting common or ordinary actions and prohibiting only actions that smack of common fraud and deception, where the likelihood of harm is substantial and courts can realistically assume the debtor's awareness of the wrongful character of the act.

Bankruptcy planning involves four major objectives: to increase the assets retained by the debtor after bankruptcy, to reduce the extent of his liabilities after bankruptcy, to maintain his relationships with selected creditors, and to benefit persons whom he wishes to prefer. The Bankruptcy Code and related case law are quite permissive in sanctioning planning to attain each of these objectives, condoning most activities in which the common indicia of fraud are not present.

\section{A. Exemptions and Fraudulent Conveyances}

Although, as a general rule, a debtor may deal freely with his property, prebankruptcy planning through transfers of property is limited by the law of

40. See Love v. Manick, 341 F.2d 680 (9th Cir. 1965) (two days prebankruptcy acceptable); Goggin v. Dudley, 72 F. Supp. 943 (S.D. Cal. 1947), aff'd per curiam, 166 F.2d 1023 (9th Cir. 1948) (one week). 
fraudulent conveyances. A transfer made by a debtor within a year before bankruptcy with intent to defraud creditors constitutes grounds for denial of a chapter 7 discharge, ${ }^{41}$ and in many cases, the transfer itself may be avoided and the property recovered for distribution to creditors.

The right to free use of his property and the law of fraud may collide when the debtor converts his assets from nonexempt to exempt status shortly before filing. In some cases, the conversion may consist of using nonexempt cash as a downpayment on a mortgage or security interest in exempt property. In other cases, nonexempt property may be sold and the proceeds used to acquire exempt property-the effect of which is to insulate the property from unsecured creditor claims in bankruptcy distribution and preserve it for the debtor, free of creditor claims. ${ }^{42}$ Although not explicitly articulated in the statute, an intent to reiterate prior law countenancing such conversions is revealed in the legislative history of the Code: "As under current law, the debtor will be permitted to convert nonexempt property into exempt property before filing a bankruptcy petition. The practice is not fraudulent as to creditors and permits the debtor to make full use of the exemptions to which he is entitled under the law."43

The suggestion that such a transfer or conversion is wrongful essentially presupposes that the consumer should enter bankruptcy in a "natural state" as to exempt property. To understand the basis of this constraint, one must first understand the character of the alleged harm in a conversion. ${ }^{44}$

The main objection to exemption conversion lies in the fact that it benefits the debtor at the expense of his unsecured creditors-although there is some risk that unencumbered property may in any event be dissipated by the debtor quite independent of any exemption conversion. Nevertheless, one observer contends that all such conversions should be precluded by analogy to preferences, since the debtor in effect receives more favored treatment vis-avis his creditors as a result of his own actions. Arguably, bankruptcy policy precludes redistribution of assets by means of such prefiling transfers. ${ }^{45}$ But the Bankruptcy Code, in fact, supplies no support for such analysis. Indeed, current bankruptcy law protects most preferences given by a consumer debtor, ${ }^{46}$ and bankruptcy policy, in fact, does not proscribe most prefiling transfers that reallocate his assets.

An exemption has a different effect in a bankruptcy context as compared to a nonbankruptcy context. Outside of bankruptcy, exemptions preserve the value of affected property to the debtor only on a transitory basis: If an exempt

41. 11 U.S.C. 8727 (1982 \& Supp. III 1985).

42. Id. §522.

43. H.R. ReP. No. 595, 95th Cong., 1st Sess. 361 (1977), reprinted in 1978 U.S. Code Cong. \& Admin. News 5963, 6317.

44. See In re Reed, 700 F.2d 986 (5th Cir. 1983); In re Adlman, 541 F.2d 999 (2d Cir. 1976); Wudrick v. Clements, 451 F.2d 988 (9th Cir. 1971); Forsberg v. Security State Bank, 15 F.2d 499 (8th Cir. 1926); In re Blum, 41 Bankr. 816 (Bankr. S.D. Fla. 1984).

45. See Eisenberg, supra note 1, at 992-97; Harris, A Reply to Theodore Eisenberg's Bankruptcy Law in Perspective, 30 UCLA L. REv. 327, 340-43 (1982).

46. See 11 U.S.C. \& 547(c)(1)-(3), (7) (1982 \& Supp. III 1985). 
asset is subsequently converted by the debtor into nonexempt property, it can be reached by his unsecured creditors. In contrast, a bankruptcy exemption permanently preserves the value of property to the debtor as against his unsecured creditors whose claims have been discharged: The exempt asset subsequently can be converted by the debtor into any form and still remain immune to the claims of his prefiling creditors.

This difference supports the conclusion that prefiling conversions are a valid planning strategy for consumer debtors. ${ }^{47}$ By sanctioning exemptions, the Bankruptcy Code defines the acceptable value that can be retained by a debtor, ${ }^{48}$ and his conversion of assets into exempt form merely exercises more fully his right to retain that value. The value limits placed on exemptions balance the desired protection for the debtor against the claims of his unsecured creditors. While in most consumer cases, few assets remain after exemptions, this result is not attributable to bankruptcy planning, but rather to the indigence of those debtors who file bankruptcy.

Bankruptcy exemption rules traditionally defer to state law, creating local variations in the extent of this protection. Although the Bankruptcy Code sets forth a separate schedule of federal exemptions as an alternative to statesanctioned exemptions, states can bar their use in bankruptcy, ${ }^{49}$ which most states do, confining debtors to only those exemptions available under state law. These state laws vary widely, but the rationale for recognizing them in bankruptcy lies in the fact that they provide a continuous legal framework for unsecured lending. While this situation gives to state exemption rules an effect that they do not have outside of bankruptcy, it does not violate their purpose. Congress simply chose to permit different schemes of protected value by adopting judgments made by other legislatures.

Other aspects of the Bankruptcy Code reflect a federal policy of protecting an individual debtor's right to plan his asset acquisitions and transfers to insure maximum benefit from his exemptions. Section 522 allows him to avoid a nonpurchase money security interest that impairs an exemption..$^{50}$ An FTC regulation expands this rule by characterizing the taking of such a security interest as an unfair trade practice. ${ }^{51}$ Similarly, the Bankruptcy Code grants the individual debtor a right to redeem exempt personal property from a security interest by paying the appraised value of the property, ${ }^{52}$ which contradicts state law rules requiring payment of the entire debt in order to redeem collateral.

47. Compare Eisenberg, supra note 1, at 992-97; Vukowich, supra note 4, at 1139-40.

48. See, e.g., 11 U.S.C. $\$ 522$ (d)(1)(5) (Supp. III 1985). A homestead exemption of a fixed dollar value is permitted, and a portion of any unused amount of this exemption may be reallocated to "any property."

49. See $1 \mathrm{~W}$. NoRTon, supra note 2.

50. 11 U.S.C. \$ 522(f) (1982).

51. See 16 C.F.R. $\$$ 444.2(9)(2) (1986).

52. 11 U.S.C. $\$ 722$ (1982). See In re Williams, 8 Bankr. 318 (Bankr. W.D. Mo. 1980); In re Miller, 4 Bankr. 305 (Bankr. E.D. Mich. 1980). 
The debtor's right to convert his assets into exempt property, although universally recognized, is defeasible where the conversion has been made with an actual intent to defraud creditors. ${ }^{53}$ This restraint is only infrequently invoked and constitutes a largely ad hoc effort to define the outer limits of fair dealing. Typically it limits conversions involving excessive value and abusive conduct such as active deception.

Fraudulent conveyance law applies to two types of transfer. ${ }^{54}$ In one, an insolvent debtor conveys property for less than its fair equivalent value, impairing his creditors' ability to collect. This type of fraudulent conveyance seldom figures in exemption conversions since in most such cases, the debtor receives equivalent value for the exchanged assets. The second type of fraudulent conveyance-more significant in this context-involves a transfer with the intent to hinder, delay, or defraud creditors.

When fraudulent conveyance law applies to an exemption conversion, two results may follow. First, denial of the exemption may make the recovered assets available for distribution to creditors, although this result is precluded in some states by local law rendering exemption claims invulnerable to allegations of fraud. ${ }^{55}$ Second, the fraud may preclude the debtor's discharge if the fraud occurred within one year of bankruptcy and was committed with an intent to hinder, delay, or defraud creditors. While denial of the exemption is a state law issue, denial of discharge is a function of federal law. ${ }^{56}$

The central issue in fraudulent conveyance cases often involves distinguishing between an intent to defraud and an intent merely to convert property. In discussing this distinction, some courts differentiate between an intent to acquire property and an intent merely to deprive creditors of value. ${ }^{57}$ This distinction is, however, unworkable. In any exemption conversion, the debtor's motive almost invariably includes a desire to safeguard assets from the claims of creditors, and this intent must be honored as long as the legitimacy of exemption planning is recognized.

A more productive analytical framework requires some extrinsic proof of fraud beyond the mere act of conversion itself. ${ }^{58}$ Such an analysis focuses on characteristics that distinguish a particular conversion and place it beyond the bounds of fair dealing. A conversion of nonexempt assets into exempt

53. See In re Reed, 700 F.2d 986, 991 (5th Cir. 1983); Miguel v. Walsh, 447 F.2d 724 (9th Cir. 1971); Shanks v. Hardin, 101 F.2d 177 (6th Cir. 1939); In re Martin, 217 F. Supp. 937 (D. Or. 1963).

54. See 11 U.S.C. $\$ 548$ (1982); 2 W. NorTon, supra note 2, at $\$ \$ 34.01-34.10$.

55. See In re Olson, 45 Bankr. 501, 504 (Bankr. D. Minn. 1984); Resnick, supra note 37, at 641-43.

56. In re Reed, 700 F.2d 986, 991 (5th Cir. 1983); In re Olson, 45 Bankr. 501, 504-05 (Bankr. D. Minn. 1984).

57. See Shanks v. Hardin, 101 F.2d 177 (6th Cir. 1939); Kangas v. Robie, 264 F. 92 (8th Cir. 1920); Resnick, supra note 37, at 638 .

58. See In re Reed, 700 F.2d 986, 990 (5th Cir. 1983); In re Adlman, 541 F.2d 999, 1003-1004 (2d Cir. 1976); Wudrick v. Clements, 451 F.2d 988, 989-90 (9th Cir. 1971); Miguel v. Walsh, 447 F.2d 724, 726-27 (9th Cir. 1971); Shanks v. Hardin, 101 F.2d 177 (6th Cir. 1939); Forsberg v. Security State Bank, 15 F.2d 499, 501 (8th Cir. 1926); In re Blum, 41 Bankr. 816, 818 (Bankr. S.D. Fla. 1984); In re Martin, 217 F. Supp. 937, 938 (D. Or. 1963). 
property is valid unless: 1) the size or value of the conversion embraces virtually all of the debtor's assets; 2) there were misrepresentations or devices used to distract creditors and dissuade them from acting to prevent the conversion; and 3) the conversion occurred in conjunction with other actions typically associated with abuse of bankruptcy. ${ }^{59}$

In re Reed ${ }^{60}$ illustrates how multiple factors coalesce into a finding of fraudulent intent. The debtor operated a small business and was also a commission salesman for a clothing company. Seven months before filing, he negotiated a postponement of collection efforts by his creditors for one year. Four months before bankruptcy, he acquired numerous collectibles financed in part by a loan he caused to be made to a corporation he had formed for tax purposes. Two months before bankruptcy, he diverted business income into a private account from which he repaid the loan that had been made to the corporation. Within weeks of filing, Reed sold the collectibles for less than their purchase price and applied the proceeds to reduce the mortgage on his homestead, which was fully exempt. A substantial number of other assets could not be accounted for. When Reed filed bankruptcy, his income was approximately $\$ 180,000$ per year. The court held that this pattern of facts supported an inference of fraudulent intent:

His rapid conversion of nonexempt assets . . f four months before bankruptcy after arranging . . . to be free of payment obligations until the following year, speaks for itself. [The debtor's] diversion of the daily receipts ... into an account unknown to his creditors ... confirm[s] his fraudulent motivation. It would constitute a perversion of the purposes of the Bankruptcy Code to permit a debtor earning $\$ 180,000$ a year to convert every one of his major nonexempt assets into sheltered property on the eve of bankruptcy ... . and then emerge washed clean of future obligation by carefully concocted immersion in bankruptcy waters. ${ }^{61}$

Although it is not fraudulent per se for a debtor to transform value into exempt assets, where other indicia of wrongdoing conduce to an overall pattern of abuse, misrepresentation, and concealment, exemption conversions will not be protected.

\section{B. Preferences}

Consistent with the principle that debtors retain control of their property before filing bankruptcy, they may generally transfer property to selected creditors even if the transfer disproportionately benefits one creditor vis-a-vis the others. The planning purpose in such transfers generally is to favor a creditor to whom the debtor feels a sentimental obligation or with whom he desires to maintain an ongoing, valued relationship. Alternatively, the intent may not infrequently be to benefit a third party who is also obligated on the debt.

59. See, e.g., In re Reed, 700 F.2d 986 (5th Cir. 1983); In re Adlman, 541 F.2d 999 (2d Cir. 1976); Wudrick v. Clements, 451 F.2d 988 (9th Cir. 1971); In re White, 221 F. Supp. 64 (N.D. Cal. 1963). Compare Resnick, supra note 37 , at 634 .

60. 700 F.2d 986 (5th Cir. 1983).

61. Id. at 990 (citations omitted). 
In bankruptcy law, a preference is a transfer of property by an insolvent debtor on account of an antecedent debt that enables the creditor to receive more than he would in a chapter 7 proceeding. ${ }^{62}$ Unlike exemption conversions, preferences do not beneficially inure to the debtor. Moreover, since preferences are, by definition, made in payment of valid debts, they do not import any suggestion of fraud. If bankruptcy occurs within ninety days (or up to a year if the favored creditor is an insider), however, a preferential transfer can be avoided and the property recovered by the trustee unless one of a number of statutory exceptions applies. ${ }^{63}$ No other sanction is imposed on the debtor.

The policy objection to preferences lies not in their intrinsic wrongfulness, but rather in the discriminatory distribution of the debtor's property they effect among his creditors. Preference rules also indirectly limit aggressive creditor collection efforts, rendering the results potentially avoidable in bankruptcy. Since the debtor actually owes an obligation to the creditor who receives the preference-an obligation that the debtor in many cases is merely electing to pay before his other obligations-avoiding the transfer denies him legitimate control of his property and penalizes the preferred creditor for accepting what he was entitled to receive under state law.

Section 547 does not require proof of wrongful intent as a condition of the avoidance power it confers on the trustee, and it potentially affects many transfers made shortly before bankruptcy whether or not planning or pressure was involved. Under current law, however, most transfers by consumers are not avoidable as preferences because section 547 insulates ordinary-course consumer credit behavior from this sanction. ${ }^{64}$ This scheme creates an opportunity for planning through preferential payment of selected creditors.

Since most ordinary-course transfers made by consumers shortly before bankruptcy are not related to bankruptcy planning, however, consumer preference law generally focuses on extraordinary transfers. Two further exceptions provide a planning framework. The first excludes transfers (including payments) to fully secured creditors. ${ }^{65}$ The significance of this exception, of course, is that many major consumer liabilities are secured, and the exclusion of these transfers effectively permits the diversion of cash resources to protect a fully encumbered asset. The second excludes any

62. 11 U.S.C. $\$ 547(b)(1982)$.

63. Id. $\$ 547(\mathrm{c})$.

64. See 2 W. NorTon, supra note 2, at $\$ \$ 32.14-32.19$. A major change enacted in preference law in 1984 modified the ordinary-course transfer protection by eliminating a condition that the payment be made within 45 days after the debt had been incurred. This 45 -day period had led to substantial litigation and had resulted in the avoidance of many normal payments owing to the determination as to when the debt had been incurred and the payment made. See In re Emerald Oil Co., 695 F.2d 833 , 835-37 (5th Cir. 1983) (debt incurred when legal liability arises); In $r e$ Iowa Premium Service Co., Inc., 695 F.2d 1109, 1111 -12 (8th Cir. 1982); Barash v. Public Finance Corp., 658 F.2d 504, 509-11 (7th Cir. 1981) (installment payments); In re Thomas Garland Inc., 19 Bankr. 920 (Bankr. E.D. Mo. 1982) (utility service debt incurred when meter read).

65. See Barash v. Public Finance Corp., 658 F.2d 504, 511 (7th Cir. 1981); Nimmer, Security Interests in Bankruptcy: An Overview of Section 547 of the Code, 17 Hous. L. Rev. 289 (1980); 2 W. NORTON supra note 2 , at $\$ 32.09$. 
transfer to a creditor if the aggregate of all property affected is less than $\$ 600^{66}$ if the claims against the debtor are "primarily" consumer debts. Measured against consumer liabilities, the protected transfers may be relatively large, providing wide latitude for selective payment.

\section{Fraudulent Acquisitions}

Fraud is a consistent theme in abuse law. It restricts not only conveyances or asset conversions by the debtor, but also his acquisition of assets on credit in contemplation of bankruptcy where the party conveying the asset is defrauded in the transaction. The critical inquiry here is precisely what consumer conduct constitutes fraudulent acquisition of property.

This issue arises under section 523, which bars from discharge any debts incurred through fraudulent misrepresentations of facts and written misrepresentations related to the debtor's financial condition. ${ }^{67}$ This exclusion focuses on the specific debt and protects the particular creditor who was defrauded. The underlying policy requires honesty by the debtor at the inception of the transaction as a condition precedent for relief (discharge) from that claim.

The fraud exception has occasioned controversy in several contexts, especially because of the difficult proof problems it presents. A common sequence involves a debtor who has obtained property on credit and files bankruptcy shortly thereafter. If a formal loan application procedure was employed, there may be questions as to whether the debtor misrepresented his financial condition and whether the creditor relied thereon. If the debtor used a credit card, the difficulties are compounded. Although there is general consensus that major credit purchases one or two days before bankruptcy are not proper, a credit card purchase involving no contemporaneous financial review is more problematic. Fraud requires proof of an actual misrepresentation, but any misrepresentation here would be only implicit. Nor is there any general policy that requires an individual debtor to discontinue use of his credit cards during periods of financial distress, although the mere act of obtaining credit in contemplation of bankruptcy entails at least apparent overreaching.

Use of a credit card shortly before bankruptcy engenders the suspicion that the debtor may have obtained the credit with no intention to pay. The image of a spending spree undertaken immediately prior to filing, followed by a bankruptcy discharge that leaves the debtor with the benefit of the acquisitions but relieved of the liabilities, is indefensible. But this situation often can be distinguished only with difficulty from one of merely excessive and ill-advised credit spending followed by belated recognition of the impossibility of payment, for which bankruptcy concededly affords a remedy.

66. 11 U.S.C. $\$ 547$ (c)(7) (Supp. III 1985).

67. Id. $\$ 523(\mathrm{a})(2)$. 
Prior to 1984, the credit card cases were in conflict. One line of authority held that if the debtor never intended to pay his debts, use of a credit card shortly before bankruptcy constituted fraud. ${ }^{68}$ Proof of such an original intent is difficult to establish, however, and in practice, this rule was limited to the most egregious cases, where large purchases had been made shortly before filing. Under the other line of authority, however, intent not to pay was not held to be fraud. ${ }^{69}$

These latter cases sanctioned planning to accumulate assets with the deliberate purpose of avoiding reciprocal obligations to pay for them. This exclusion of misrepresented intent placed an important limitation on the availability of fraud to bar a debtor's discharge where the credit problems involved mere nonperformance of contract. Overlying this split of authority, moreover, there was also a dispute about whether the debtor had misrepresented his financial condition in a form sufficient to satisfy the discharge exception set forth in section 523(a)(2). Like its predecessor, this provision requires a written misrepresentation by the debtor of his financial condition; but the only writing in the credit card sale is the charge receipt, which contains no explicit representation about the debtor's financial condition.

A 1984 amendment to section 523, however, establishes a presumption that consumer debt incurred shortly before bankruptcy is nondischargeable if it is for goods and services unrelated to the reasonable needs of the debtor, is owed to a single creditor and aggregates more than $\$ 500$, and was incurred within forty days of bankruptcy; or if it consists of cash advances aggregating more than $\$ 1000$ obtained within twenty days. ${ }^{70}$ This presumption overrules cases holding misrepresented intent to pay not to be fraudulent and, in effect, defines a particular type of abuse and a form of fraud uniquely associated with bankruptcy proceedings. As in other contexts, the abuse standard entails, at least in part, a measure of excess and overreaching gauged in discernable monetary terms.

\section{$\mathrm{V}$ \\ Abuse and Chapter 13}

Under chapter 13, as contrasted with chapter 7, the debtor can retain his assets rather than being compelled to surrender them for liquidation. In return for this dispensation, chapter 13 requires the debtor to make payments to his creditors over a period of time pursuant to a plan that has been proposed by the debtor and confirmed by the bankruptcy court. Confirmation standards invoke both economic considerations and subjective measures relating to good faith and feasibility. Under the newly revised

68. See In re Senty, 42 Bankr. 456, 459-61 (Bankr. S.D.N.Y. 1984); In re Buford, 25 Bankr. 477 (Bankr. S.D.N.Y. 1982); In re Stewart, 7 Bankr. 551, 554-56 (Bankr. M.D. Ga. 1980).

69. See Sears Roebuck \& Co. v. Wood, 571 F.2d 284 (5th Cir. 1978); Davison-Paxon Co. v. Caldwell, 115 F.2d 189, $191-92$ (5th Cir. 1940), cert. denied, 313 U.S. 564 (1941).

70. 11 U.S.C. $\$ 523(\mathrm{a})(2)$ (c) (Supp. III 1985). 
chapter 13, as a condition of confirmation, creditors may insist that the debtor commit all of his disposable earnings to payments under the plan. ${ }^{71}$

Disputes about the role of chapter 13 in consumer credit were central to the controversy that swirled about consumer bankruptcy in 1984. Issues of abuse in chapter 13 may arise in two ways. First, it may be an abuse of bankruptcy for an individual debtor to file under chapter 7 instead of chapter 13 if he has sufficient disposable income substantially to pay his debts. This issue now arises in the context of "substantial abuse" under section 707(b) and focuses on whether debtors can be forced into a wage-based bankruptcy proceeding. Second, the circumstances surrounding filing or the formulation of a plan under chapter 13 may raise sui generis issues about abuse of chapter 13 relief itself.

There is no single format analogous to section 707(b) under which to discuss abuse in chapter 13. Issues of abuse of chapter 13 are raised under the confirmation standard that a plan be proposed in good faith, ${ }^{72}$ under standards for relief from the automatic stay for cause, ${ }^{73}$ or under standards for dismissing a case or converting it from chapter 13 to chapter 7 . The standards for dismissal in section 1307 include a variety of specific events and general cause. ${ }^{74}$ In addition, several specific abuses of chapter 13 were explicitly dealt with in the 1984 amendments.

\section{A. Selection of Chapter 13 and Incentives}

A definition of bankruptcy abuse in chapter 13 requires an understanding of what might lead a debtor to use that procedure instead of proceeding under chapter 7 . As an initial premise, chapter 13 is seldom chosen in order to reduce transfers of value to creditors. To be confirmed, a chapter 13 plan must contemplate distribution to creditors of assets with a present value not less than that of the assets they would have received in a chapter 7 liquidation. ${ }^{75}$ Moreover, if an unsecured creditor objects, the plan must provide for full payment or for commitment of all of the debtor's disposable income to the plan over the three-year period. ${ }^{76}$ During the pendency of the plan, the debtor and his creditors have the right to petition to modify the

71. Id. \& 1325(b).

72. 11 U.S.C. \& 1325(a)(3) (1982). See Cyr, The Chapter 13 "Good Faith" Tempest: Analysis and Proposal for Change, 55 Am. Bankr. L.J. 271 (1981).

73. 11 U.S.C. \& 362(d)(1) (1982). See Nimmer, supra note 36; Jackson, supra note 36.

74. 11 U.S.C. $\$ 1307$ (c) (1982) requires a request by a party in interest but allows the court to dismiss or convert the case to a chapter 7 proceeding for "cause," defined as including unreasonable delay prejudicial to creditors, failure to file a plan on a timely basis, and a failure to commence payments required before confirmation under new section 1326. As to general concepts of "cause," compare In re Baker, 736 F.2d 481 (8th Cir. 1984) (fact that a chapter 7 petition had been filed within six years), with In re Beauty, 42 Bankr. 655 (Bankr. E.D. La. 1984) (fact that chapter 13 petition had been filed within a month after chapter 7 discharge and applied only to secured claims that survived the earlier cause for dismissal).

75. 11 U.S.C. $\$ 1325$ (a)(4) (1982). See In re Knipping, 40 Bankr. 865 (Bankr. W.D. La. 1984); In re Hawkins, 33 Bankr. 908 (Bankr. S.D.N.Y. 1983) (as to debts nondischargeable in chapter 7).

76. 11 U.S.C. \& $1325(b)(1)(1982)$. 
plan, presumably to adjust its terms to meet changed income and other relevant circumstances. ${ }^{77}$

In addition to requiring transfers of equal or greater value to creditors, a chapter 13 plan commonly places longer-term restraints on the debtor than does a chapter 7 proceeding. In a liquidation, the entire case is often completed within several months of filing. In contrast, chapter 13 plans typically require performance over a period of years, during which time the debtor's disposable income is diverted into payments to his creditors.

Given these comparative drawbacks, what motivates an individual to undertake a greater obligation under chapter 13? One possible explanation involves a rational choice based on informed assessment of tangible incentives. Consistent with encouraging its use, chapter 13 provides relief that may be superior to that available under chapter 7 . The chapter 13 discharge involves fewer exceptions than does the chapter 7 discharge. ${ }^{78}$ Chapter 13 procedures permit retention of encumbered property despite prior defaults. ${ }^{79}$ Furthermore, social conceptions and credit reports traditionally favor debtors who use chapter 13 over those who use chapter 7 . This reputational value reinforces the perceived and actual advantages of chapter 13 vis-a-vis chapter 7 and persuades some debtors to regard it more favorably despite the greater transfer of value to creditors that it usually entails.

Many benefits in chapter 13 are contextually variant, however, and are present only for a small fraction of all consumers. For example, to encourage its use, a completed chapter 13 proceeding provides a broader discharge than does a chapter 7 proceeding, overriding most of the exceptions to discharge specified under section 523. Thus, a debtor who has obtained money through false pretenses or a student loan-debts that are nondischargeable under chapter $7^{80}$-may be discharged of either debt under chapter 13.81 But this incentive operates only if the debtor has debts of this type, anticipates that an exception to their discharge may be interposed in chapter 7, and actually expects to perform the plan in full. Similarly, another variable incentive is that a chapter 13 debtor retains all of his property, including items that are not exempt. ${ }^{82}$ This feature of chapter 13 allows the more financially substantial debtor to preserve assets that otherwise would be relinquished, but it is unimportant to most consumer debtors, who typically have little or no nonexempt property.

77. 11 U.S.C. $\$ 1329$ (a) (Supp. III 1985) was modified in 1984 expressly to include the possiblity of modification of the plan after confirmation at the request of the holder of an allowed unsecured claim.

78. Compare 11 U.S.C. $\$ 1328$ (a) (1982) with 11 U.S.C. § 523(a) (1982).

79. 11 U.S.C. \& 1322(b)(5) (1982).

80. 11 U.S.C. \& 523(a)(2), (8) (1982 \& Supp. III 1985).

81. See In re Gibson, 45 Bankr. 783 (Bankr. N.D. Ga. 1985); In re Prine, 10 Bankr. 87 (Bankr. D. Idaho 1981).

82. 11 U.S.C. \& 1306(b) (1982). 
Another distinctive aspect of a chapter 13 proceeding is its effect on secured credit. Unless invalidated by a specific provision of the Code, a security interest remains enforceable in and after bankruptcy despite the fact that the debtor is discharged of personal liability for the underlying debt. In chapter 7 proceedings, this rule places the debtor at risk of losing encumbered property unless he is able to reach an accommodation with the secured creditor or has sufficient cash to redeem the property from the security interest. Chapter 13 proceedings, however, give the debtor a right to force a restructured payment schedule on a secured creditor in nonresidential property ${ }^{89}$ and to delay or avert foreclosure of a security interest by curing default over a reasonable time. ${ }^{84}$

An alternative explanation for chapter 13 use invokes the overriding influence of environmental and emotional factors. Many individuals desire to pay their debts, and chapter 13 is the bankruptcy option best suited to this objective. Other factors that may incline a debtor towards chapter 13 are the preferences of lawyers, the personally perceived stigma of the alternatives, the preferences of local judges, and the behavior expectations in particular judicial districts. The debtor's choice in the matter is, in sum, strongly influenced by the sociolegal environment of his decisions. ${ }^{85}$

Chapter 13 provides the debtor relief from creditor pressure while he is seeking to pay his debts. A chapter 13 petition automatically stays creditors' efforts to collect, producing a less harassed environment for the debtor. For the debtor who desires to make full payment, chapter 13 confirmation standards permit virtually complete control over the terms of a payment program that will bind all parties. Consequently, chapter 13 enables the debtor to design a payment schedule that can be imposed on all of his creditors without the need to negotiate independently with each one of them.

It is not an abuse of chapter 13 for a debtor to respond positively to these incentives. If abuses exist, they are associated with seeking to obtain the benefits without undertaking the commensurate obligations of chapter 13 . We turn briefly to several illustrations of behavior often associated with perceived abuse.

83. 11 U.S.C. \& 1322(b)(2), (5) (1984). See In re Carroll, 8 Bankr. Ct. Dec. (CRR) 504 (Bankr. 9th Cir. 1981); In re Redding, 34 Bankr. 971 (Bankr. M.D. Penn. 1983); In re Davis, 20 Bankr. 212 (Bankr. C.D. Ill. 1982).

84. 11 U.S.C. \$ 1322(b)(2) (1982). See Central Federal Savings \& Loan v. King, 23 Bankr. 779 (Bankr. 9th Cir. 1982) (31 months to cure is reasonable time); Philadelphia Saving Fund Society v. Stewart, 16 Bankr. 460, 461-62 (Bankr. E.D. Pa. 1981) (40 months to cure reasonable); In re Hailey, 17 Bankr. 167 (Bankr. S.D. Fla. 1982) (12 months to cure not reasonable). A mortgage default can be cured after the underlying debt has been accelerated. See In re Clark, 738 F.2d 869, 874 (7th Cir. 1984); Grubbs v. Houston First American Savings Ass'n., 730 F.2d 236, 240-42 (5th Cir. 1984); In re Taddeo, 685 F.2d 24, 26-29 (2d Cir. 1982).

85. See Report of the Comm'n on the Bankruptcy Laws of the United States, pt. 1 , at 157. 62 (1973); Warren, supra note 6, at 1344-46; Vukowich, supra note 6, at 1364-65. 


\section{B. Minimal Payment and Bad Faith}

Chapter 13 is perceived as a payment remedy designed for debtors willing to commit their income to the substantial satisfaction of their debts. This view justifies the more generous relief available under chapter 13 and also explains why a chapter 13 proceeding is less damaging to the debtor's financial standing than a chapter 7 proceeding.

Under the Bankruptcy Code, however, a chapter 13 plan proposed in good faith can be confirmed without consent of creditors if they will receive at least as much as they would have received in a chapter 7 liquidation. This economic "best interests" standard was intended to neutralize creditor power to veto plans that proposed less than 100 percent payment, but it created unexpected results. Since there would be no assets available in most consumer cases for distribution to creditors under chapter 7 , chapter 13 plans that contemplated little or no payment to the unsecured creditors could be confirmed under the economic standard.

The question of whether zero payment plans were an abuse of chapter 13 had preoccupied the courts and Congress prior to 1978. The courts focused on the requirement that a chapter 13 plan be proposed in good faith. To understand the controversy, however, it is important to distingush two issues. The first is whether a minimal payment plan evidences bad faith and is abusive per se. The second is to what extent a debtor may obtain the extended benefits available under chapter 13 without making substantial payment to creditors. ${ }^{86}$

Early cases treated the first issue with mixed results. ${ }^{87}$ In one view, the best interests standard defined the required minimum payment and precluded further restriction in the guise of a good faith test. The contrary view regarded some payment to be essential and the use of chapter 13 by a debtor without undertaking to make any payments to be abusive.

Even before the 1984 amendments, however, this pure issue had become largely historical. Other than as a violation of the spirit of chapter 13, it is difficult to identify any harm resulting from the typical zero payment plan in the ordinary case where the scope of the debtor's discharge and his retention of property under chapter 13 are no different than would be the case under chapter 7. The chapter 13 label might perhaps mislead later creditors, but this is an insufficient reason to develop an elaborate conception of abuse based on good faith standards. Quite correctly, the appellate courts rejected the suggestion that low payments constituted bad faith per se, ${ }^{88}$ one court observing:

86. See In re Gibson, 45 Bankr. 783 (Bankr. N.D. Ga. 1985); In re Prine, 10 Bankr. 87 (Bankr. D. Idaho 1981) (embezzlement claim). Compare In re Sotter, 28 Bankr. 201, 204-06 (Bankr. S.D.N.Y. 1983) (bad faith where debts result of criminal conduct), with In re Chase, 43 Bankr. 739 (Bankr. D. Md. 1984) (no confirmation where debts result of criminal conduct), and In re Stein, 36 Bankr. 521 , 523-24 (Bankr. S.D. Fla. 1983) (no confirmation where sole purpose was to modify secured claim).

87. See, e.g., In re Iacovini, 2 Bankr. 256, 265-67 (Bankr. D. Utah 1980).

88. See In re Hines, 723 F.2d 333 (3d Cir. 1983); Public Finance Corp. v. Freeman, 712 F.2d 219, 221 (5th Cir. 1983); In re Kitchens, 702 F.2d 885 (11th Cir. 1983); United States v. Estus, 695 F.2d 
[T] he plain language of the statute precludes importation of a per se rule of substantial repayment into the "good faith" requirement .... Quite simply, had Congress intended that such repayment be a condition precedent to confirmation of all Chapter 13 plans it could have in fact explicitly so stated .... Congress did in fact explicitly set a minimum repayment level . . . but that limit is not one requiring substantial repayment in every plan. 89

The appellate courts did not, however, reject all consideration of the quantum of proposed payment in a chapter 13 plan as a determinant of good faith. It was one factor to be considered in conjunction with such other factors as the debtor's job history and prospects, his living expenses, the nature and amount of his unsecured debt, including the manner in which the debt was incurred, his compliance with obligations accurately to report income and expenses, and the extent to which any unusual events may have influenced the bankruptcy filing or the debtor's financial condition. ${ }^{90}$

Moreover, the appellate decisions defined two general fact patterns that suggested bad faith. The first consisted of a minimal payment proposal in the face of a substantial ability by the debtor to pay. ${ }^{91}$ This form of abuse generated the reference by several courts to the job prospects and earning history of the debtor. The second pattern consisted of an attempt by the debtor to use chapter 13 to obtain its special benefits without making a best effort to pay. ${ }^{92}$ For example, a zero payment plan to discharge an otherwise nondischargeable debt might signal bad faith if unaccompanied by a best effort attempt to make payments. As one court noted:

Congress never intended Chapter 13 to serve as a means of avoiding liability by way of a discharge absent an honest effort to pay obligations. . . . Bad faith may be found where the primary purpose . . . is to obtain a discharge of an otherwise nondischargeable debt through a nominal payment plan which does not indicate a sincere desire to pay creditors to the best of his ability. ${ }^{93}$

This analysis was substantially changed, however, by the 1984 amendments. The economic standard for confirmation now has two tiers. If no unsecured creditor objects to a proposed payment schedule, the plan can be confirmed if unsecured creditors receive no less than they would have received under a chapter 7 liquidation. But if an unsecured creditor does

311, 316-17 (8th Cir. 1982); Memphis Bank \& Trust Co. v. Whitman, 692 F.2d 427 (6th Cir. 1982); Deans v. O'Donnell, 692 F.2d 968 (4th Cir. 1982); Barnes v. Whelan, 689 F.2d 193, 197-200 (D.C. Cir. 1982).

89. Deans v. O'Donnell, 692 F.2d 968, 970-71 (4th Cir. 1982).

90. See In re Hines, 723 F.2d 333 (3d Cir. 1983); Public Finance Corp. v. Freeman, 712 F.2d 219, 221 (5th Cir. 1983); In re Kitchens, 702 F.2d 885, 888-89 (11th Cir. 1983); Memphis Bank \& Trust Co. v. Whitman, 692 F.2d 427, 431 -32 (6th Cir. 1982); Deans v. O'Donnell, 692 F.2d 968, 972 (4th Cir. 1982); Ravenot v. Rimgale, 669 F.2d 426, 431-33 (7th Cir. 1982).

91. See, e.g., In re Kitchens, 702 F.2d 885 (1 l th Cir. 1983); Deans v. O'Donnell, 692 F.2d 968 (4th Cir. 1982).

92. See, e.g., Ravenot v. Rimgale, 669 F.2d 426 (7th Cir. 1982).

93. In re Keiser, 35 Bankr. 496, 498 (Bankr. D. Del. 1983). See In re Gibson, 45 Bankr. 783 (Bankr. N.D. Ga. 1985) (student loan discharged); In re Prine, 10 Bankr. 87 (Bankr. D. Idaho 1981) (embezzlement claim). Compare In re Sotter, 28 Bankr. 201, 204-06 (Bankr. S.D.N.Y. 1983) (bad faith where debts result of criminal conduct), with In re Chase, 43 Bankr. 739, 744-45 (Bankr. D. Md. 1984) (no confirmation where debt result of criminal conduct), and In re Stein, 36 Bankr. 633 (Bankr. S.D. Fla. 1983) (no confirmation where sole purpose was to modify secured claim). 
object to a plan that proposes less than payment in full, the plan cannot be confirmed unless "all of the debtor's disposable income to be received" over the next three years "will be applied to make payment under the plan."94 Disposable income is defined as the amount beyond that "reasonably necessary" for support of the debtor and dependents and for maintaining the debtor's business. ${ }^{95}$

These standards exclude the possibility that low payment, without more, can successfully be adduced as an independent and self-sufficient ground of bad faith. Whether the standards also alter the case law in which minimal payment is a factor in a broader analysis of abuse is less clear. Conceivably, a minimal payment plan coupled with otherwise nondischargeable debts can still be described as abusive, but the better approach would be to reject this analysis. Chapter 13 gives creditors an opportunity to object to an inadequate proposal and forces the debtor to apply his disposable income to the payment of his obligations. Creditors can, moreover, obtain judicial modification of payment schedules if the debtor's disposable income increases. Requiring a debtor under chapter 13 to propose payment to his creditors of more than his disposable income creates an insuperable obstacle to bankruptcy relief not warranted in equity or law. Likewise, rejecting a payment proposal to which the creditors have not objected is unduly solicitous of the creditors' rights. It should not be deemed abusive for a debtor to comply with the standards of chapter 13 in order to attain its enhanced benefits if he has fully committed his disposable earnings to the proposed plan, even if these earnings actually permit only meager payment of his debts.

\section{Delay, Lack of Effort, and Multiple Filings}

As the discussion of minimal payment plans indicates, one element of abuse law relating to chapter 13 is the requirement that the debtor's motivation be consistent with the intended purpose and scope of the remedy. While a mismatch between motivation and system objective is most apparent in connection with meaningful payment issues, other aspects of this theme arise in connection with a developing law of abuse and require at least brief comment.

One form of abuse under chapter 13 consists of the debtor's efforts to use the petition and the resulting automatic stay to delay a creditor's foreclosure against encumbered property. Without more, such tactics are not necessarily inconsistent with the underlying rationale of chapter 13. If the debtor, in fact, intends to implement a payment schedule or to cure a default through his plan, he is entitled to protection from unconstructive creditor harassment while seeking to do so. Delaying creditor enforcement action in this context does not necessarily constitute abuse; abuse exists only where the intention to

94. 11 U.S.C. \& 1325(b)(1)(B) (Supp. III 1985).

95. Id. \& $1325(\mathrm{~b})(2)$. 
delay is not accompanied by an intent to perform a confirmable plan under chapter 13.

A fact pattern that often raises questions is seen when a chapter 13 petition is filed shortly before the completion of a foreclosure sale. Although the language in some cases might suggest that a filing on the eve of a foreclosure sale is an abuse of bankruptcy and bad faith, ${ }^{96}$ this analysis misinterprets the Code. Unless more is established, the use of bankruptcy to preserve property to the debtor in the face of a foreclosure is permitted; abuse arises only if delay is the debtor's sole objective and he has no intent seriously to work through the chapter 13 proceeding. Creditors are further protected by express statutory requirements concerning the timeliness of payments proposed in a plan, which, under section 1326, unless a contrary court order is obtained, must be commenced within thirty days after the plan is filed. Failure by the debtor so to conform is expressly defined as a basis for dismissal.

Use of chapter 13 to delay creditors without intent to make payments may also be evidenced by repetitive petitions filed after each prior case is dismissed or the creditor obtains an order granting relief from the stay. Although multiple filings under chapter 13 were not expressly barred under prior law, courts relied on concepts of good faith or abuse of the spirit of chapter 13 to justify dismissal of such cases for cause. ${ }^{97}$ In some instances, in order to forestall debtor manipulation of the court, a dismissal was coupled with an order enjoining the debtor from filing another petition within a specified time period.

Multiple filings over a brief time period in the face of impending foreclosure creates a presumption of abuse. Some cases of repeated filings, however, do not involve bad faith efforts to use chapter 13 solely for purposes of obtaining a delay, but rather can be explained in terms of the changing financial circumstances of the debtor. ${ }^{98}$ The Code now amplifies the framework for dealing with this form of abuse. Section 109(f) provides that no individual can be a debtor in a case within 180 days after a prior case was (1) dismissed for willful failure to abide by court orders, or (2) voluntarily dismissed at the request of the debtor after the filing of a request for relief from the automatic stay. This approach defines the kind of cases of recurrent filing that are most likely to constitute the abusive use of bankruptcy to frustrate efforts at foreclosure. ${ }^{99}$ This is especially likely in the context of a

96. See In re Gates, 42 Bankr. 4 (Bankr. N.D. Ga. 1983).

97. 11 U.S.C. \& 1307 (c)(1)(3) (1982); In re Bolton, 43 Bankr. 48 (Bankr. E.D.N.Y. 1984); In re Gates, 42 Bankr. 4 (Bankr. N.D. Ga. 1983) (no confirmation third plan); In re Nimmo, 39 Bankr. 5 (Bankr. D. N.M. 1984); In re Artishon, 39 Bankr. 890 (Bankr. D. Minn. 1984); In re Marit-Trigona, 35 Bankr. 596 (Bankr. S.D.N.Y. 1983); Steele v. Mortgage Corp. of the South, 34 Bankr. 172 (Bankr. M.D. Ala. 1983).

98. See Johnson v. Vanguard Holding Corp. 708 F.2d 865, 868 (2d Cir. 1983) (second filing not bad faith); In re Bolton, 43 Bankr. 48, $51-52$ (Bankr. E.D.N.Y. 1984) (changed circumstances not proven); In re Smith, 43 Bankr. 319, 321 -22 (Bankr. E.D. N.C. 1984) (fourth plan confirmed owing to changed circumstances).

99. 11 U.S.C. $\$ 109$ (f) (Supp. III 1985). See In re Patel, 48 Bankr. 418 (Bankr. M.D. Ala. 1985). 
voluntary dismissal following a motion for relief from the stay. In circumstances not expressly covered by the exclusionary standards, preexisting case law continues to apply.

\section{VI}

\section{Conclusion}

This article describes several themes that define a concept of consumer abuse of bankruptcy and correlatively suggest an acceptable role for bankruptcy in the consumer credit context. In this connection, the article discusses when and how a consumer debtor appropriately can rely on bankruptcy as an alternative to performing a credit contract, which entails the examination of various assumptions about the performance of such contracts and their underlying and often controversial policy predicates.

The developing law in this area mediates among competing policies that reflect diametric conceptions of the desired use, availability, and planning of bankruptcy by consumer debtors. It defines acceptable debtor behavior in equitable terms and provides sanctions designed to avert egregious debtor overreaching and fraud. In thus excluding from bankruptcy only those extreme cases about which some consensus can be established, the law of abuse properly leaves the primary decision largely in the hands of the debtor.

Under current law, an individual debtor's access to bankruptcy turns on equitable considerations rather than on absolute right. The standards of substantial abuse in chapter 7 and good faith or cause in chapter 13 reflect this position. The preeminent equitable consideration links the debtor's right to bankruptcy relief to some actual need for the remedy. Need is defined loosely but is a function not only of the debtor's assets, but also of the relationship between his expected future income and his existing debt and expected future expenses. The disposable future income standard appliesalbeit differently-in both chapter 13 and chapter 7. Chapter 13 cannot be used for income shifting so as to block the access of an existing creditor to this future asset. Chapter 7 , on the other hand, permits income shifting, but sanctions dismissal of the debtor's petition in extreme cases of attempted protection of substantial future income.

A need standard is consonant with the policy assumption that a debtor should elect bankruptcy for reasons consistent with the ultimate character of the remedy-granting a discharge to a debtor who has complied with the requirements for submission of data, income, and assets. Abuse law does not justify broad speculation about the motives of the debtor. Nevertheless, extreme cases of multiple filing and voluntary dismissal, unjustified delay, and comprehensive failure to conform with reporting requirements constitute abuse.

The standards refer to extreme cases, and abuse law deals with the degree and substantiality of effect of the debtor's conduct. This line-drawing is inherently and ultimately uncertain. It occurs under standards of substantial abuse in chapter 7 , in distinguishing permitted from fraudulent conversion of 
assets, and in defining bad faith or cause. In these and other settings, the debtor retains substantial discretion, but creditor interests supply a growing counterweight as that discretion is exploited to the substantial, avoidable, and unnecessary detriment of creditors. The line between a legal right to exercise choices for personal benefit and the equitable restraints on that right is not clear, nor can it ever become so. Nevertheless, the line is recurrently and necessarily drawn either by explicit decision or by de facto acceptance of conduct that pushes at appropriate limits.

Much of the law of abuse is couched in language of fraud, misrepresentation, and concealment. This language identifies various transactions through which the debtor seeks unmerited advantage by manipulating or misrepresenting information, creating fictitious transfers, and failing to disclose or report. Abuse in the form of fraud may entail conveyances from the debtor to third parties or acquisitions of property by the debtor through misrepresentation of status or current intent. In each case, the doctrinal guide couples intent to harm creditors with nondisclosure or misrepresentation of pertinent facts. This coupling must be distinguished from acceptable intentions to obtain personal benefit. Once again, the standards define the bounds of accepted fair dealing and provide sanctions against extreme deviations.

This article describes an initial framework that defines the law of abuse and its role in structuring the application of bankruptcy in the consumer credit area. The restraints imposed by abuse standards largely affect only the periphery and permit debtors substantial latitude. This flexibility is proper, but there are increasingly urgent needs to develop more coherent conceptions of both overall bankruptcy policy and the role of bankruptcy in the context of current consumer credit transactions. 